\title{
小型超音速実験機全機フラッタ模型風洞試験について*1 Wind Tunnel Test of Full Span Flutter Models of Small Supersonic Experimental Aircraft
}

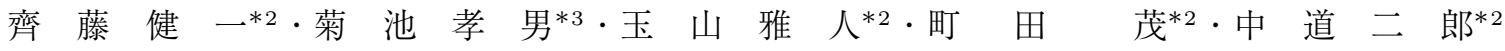 \\ Kenichi Saitoh, Takao Kikuchi, Masato Tamayama, Shigeru Machida and Jiro Nakamichi
}

Key Words : Super Sonic Transport, Flutter, Wind Tunnel Test

\begin{abstract}
Three wind tunnel tests for flutter have been conducted under the development of the National Experimental Airplane for Supersonic Transport (NEXST-1) of JAXA launched in 2005. Three kinds of flutter were investigated by using three different wind tunnel models at that time. Discussion of this paper is mostly on the one for a main wing model. The planform of the NEXST-1 wing is a cranked arrow having warp in the out of plane direction. For flutter, the model showed the so called transonic dip of which bottom speed was at Mach 1.02. It was also subjected to limit cycle oscillation (LCO) in the transonic regime. The flutter was dominantly the bending of the out board wing. In the design stage of the NEXST-1, a $20 \%$ reduction was anticipated for the transonic regime by the flutter analysis with the linear aerodynamic theory. The wind tunnel experiment resulted in $21 \%$ lower in the flutter speed that was slightly higher than the assumption. The NEXST-1 aircraft was launched in the piggy back style by the solid rocket booster. Therefore, the flutter was also investigated for this launching configuration. The flutter speed reduction in this case was $27 \%$, which was larger than that for a sole airframe. As a consequence, the design methodology for transonic flutter is thought to be confirmed for supersonic flight vehicles.
\end{abstract}

記 号の説 明

\author{
$P_{0}:$ 総圧 \\ $\rho:$ 空気密度 \\ $\rho_{\mathrm{SL}}:$ 海面上の標準大気空気密度 \\ $\mu$ : 質量比 \\ $T:$ 気体温度 \\ $M:$ マッハ数 \\ $m:$ 翼質量 \\ $q_{\mathrm{d}}:$ 動圧 \\ $\omega$ : 角振動数 \\ $\gamma:$ 比熱比 \\ $b:$ 代表半翼弦長 \\ $l:$ スパン長 \\ $i$ : 虚数単位 \\ $V_{\mathrm{EAS}}$ ：等価対気速度 \\ $V_{\mathrm{TAS}}$ ：真対気速度 \\ $C_{l \alpha}:$ 揚力傾斜 \\ $H$ : 風洞測定部高さ \\ $k:$ 無次元振動数 \\ $U:$ 速度 \\ $R:$ 気体定数 \\ $(\quad)_{\infty}$ ：一様流に関する諸量
}

\footnotetext{
*1 (C) 2011 日本航空宇宙学会

平成 23 年 5 月 24 日原稿受付

*2 宇宙航空研究開発機構

*3 元 宇宙航空研究開発機構
}

1.は じめ に

1963 年に米国で超音速旅客機（Super Sonic Transport; SST）の開発プログラム（U. S. SST program）が正式に スタートした ${ }^{1)}$. NASA が行った予備調査 SCAT（Supersonic Commercial Air Transport) では -4, - 15, -16, -17 の 4 種類の機体が提案されボーイング社やロッキード 社が検討した。 このうち可変翼機であった SCAT-15 は後 にダブルデルタ固定翼機 SCAT-15F として提案され，そ の後の開発のベースとなっている. 同年に米国連邦航空局 (FAA) が出した提案要求に対してボーイング社やロッキー ド社が応募して B-2707-200, L-2000 を提示し, ボーイン グ社が選ばれている. B-2707-200は可変翼機であったが その後 SCAT-15F をベースとした固定翼機の B-2707-300 へ設計変更された。しかしながら米国での SST プロジェ クトが終了した 1971 年の時点ではフラッタに関する問題 は解決されていなかった。 1972 年以降 Advanced Supersonic Technology（AST）プログラムとして SST の研究は 続けられ，1974年にSupersonic Cruise Aircraft Research (SCAR), 1979 年 Supersonic Cruise Research (SCR) と 名称を変えながら受け継がれている。 その間, 解析技術の 進歩により, 構造解析コードATLAS を用いてフラッタに 対する検討が進められ, 強度設計結果に対して $1503 \mathrm{~kg}$ の 重量増加のほか, 翼厚増加による抵抗係数の増加, さらに 設計急降下速度を $93 \mathrm{~km} / \mathrm{hr}$ (50 knot）低下させることに よりフラッタ問題を解決することとしている2). 1986 年か ら NASA の契約の下, ダグラス社やボーイング社が High 
Speed Civil Transport（HSCT）の研究を行い, 1990 年 から NASA は High Speed Research（HSR）プログラム を行っている。この間 AST-200 や Reference H と呼ばれ るモデルに対する検討が進められ，遷音速デイップに対す る桁位置やフィン等パラメトリックな研究が進められた。

一方英仏開発の Concorde は旅客飛行まで実現させてお り, フラッ夕模型による試験や 3 機の飛行試験等, 開発の いずれのステージでも主翼に関するモードに問題は生じて いない. 最もフラッ夕速度余裕の少ないモードは, 垂直フィ ンとラダーに関するモードとされている3゙.

遷音速領域に扮ける SCAT-15F 全機フラッタ模型のフ ラッタ試験は，翼面上の垂直フィンあり，なしの形態で行 われているが, 双方とも Mach 0.92 でフラッタ動圧が最小 となり，より低下量が大きいフィンなし形態に扔いてその 低下量は Mach 0.81 に対して $10 \%$ 以下となっている4). 垂 直フィンを外した場合は，フィンありに対して Mach 0.80 から 0.92 の間でフラッタ動圧が約 $14 \%$ 上昇している. 文 献 5) では, クランクトアロー翼に対するエンジンナセルの 有無の影響について実験によるデー夕が得られている。ナ セルがあるとき遷音速デイップは深くなり，ナセルなしの とき，Mach 0.72 付近に対して Mach 0.97 で動圧低下量は $20 \%$ あるが，ナセルがあるときは Mach 0.75 付近に対し て Mach 1.01 で 30\%の低下となっている。 これはディップ の底自体は同程度のフラッ夕動圧となっているが, 亜音速領 域ではナセルがあることによりフラッ夕動圧が高くなって いるためである. 文献 6) では同じ模型でエンジンナセルの ない状態において翼面上の垂直フィンの有無拉よび迎角の 影響について実験が行われた。この実験ではフィンのないク リーン形態ではゼロ揚力状態（迎角 $0^{\circ}$ ）で Mach 0.95 のと きフラッタ速度が最低となり, Mach 0.70 に対して $11 \%$ の 速度低下となっている。迎角については，フィンなしのとき は Mach 0.90, フィンありのときは Mach 0.95 において, 双方とも $4^{\circ}$ のとき $0^{\circ}$ に対して $13 \%$ の動圧低下であった。 フィンの有無については, 前述の試験とは逆にフィンがあ るときのほうがフラッ夕速度が高く, 解析により空力的で はなく構造的影響が大きいとされている。 その後も桁の構 造やスパン長の影響等に関する試験が行われている7,8).

我が国で研究が進められた小型超音速実験機は，巡航マッ 八数 2.0 , 座席数 300 席クラスの次世代大型超音速旅客機 を想定した $11 \%$ のスケールモデルで，自然層流翼による抵 抗低減とそれを実現するための逆問題設計法等の空力設計 技術の実証を主な目的として開発された。これらの空力設 計技術により機体形状に扔いて主翼はワープ形状をもった クランクトアロー翼，胴体はエリアルール適用胴体である。 実験機は 2002 年の第 1 回飛行実験失敗の後, 大幅な改修 設計を行い，2005 年第 2 回飛行実験を成功裏に終えた，本 論文は, 第 1 回飛行実験前の初期段階の空力弾性設計にお いて行ったフラッタ模型風洞試験研究を整理再検討したも のである.

\section{2. 実験機の空力弾性設計}

2.1 実験機および飛行試験の概要 小型超音速実験機 の飛行実験計画では打上げ時には固体ロケットブースター に実験機を取り付け, 最大高度約 $20 \mathrm{~km}$, 最大マッ八数 2.5 に到達しロケットから切り離したのち, 滑空しながら巡航 マッハ数 2.0 で空力デー夕を取得し, その後减速したのち パラシュート開傘，エアバック展開により機体を回収する.

実験機主翼の翼根翼厚比は $3.7 \%$ で内翼は多桁構造となっ ている。キンクより先は翼厚比 $3.0 \%$ で十分な厚みが確保 できないことから，外翼はアルミ中実構造となった。また 尾翼も同様に中実構造となっている。胴体はマルチフレー ムモノコック構造で内部に計測機器やエアバックを搭載し, また尾部にはパラシュートを搭載している。これらの主構 造材料は主に 2124-T851，2024-T62 などのアルミ合金で ある。

2.2 実験機の空力弾性設計方針 解析精度の向上や, 遷 音速領域におけるフラッタ現象の解明などに伴い，フラッ 夕設計に関するFAA の規定は 1992 年に改訂され，輸送機 $\mathrm{T}$ 類に対する設計時のフラッタ速度余裕要求は等価対気速 度でそれまでの $20 \%$ から $15 \%$ となり，より小さな余裕で設 計されるようになった，超音速機においても一般にフラッ 夕が最酷となるのは遷音速領域であって, 同速度領域にお けるフラッタ速度の低下，いわゆる遷音速デイップに対す る十分な検討が必要となる，ただし本実験機においてはス ケール効果により重量に対する軽量化の要求が厳しくない ことなどから，フラッタ設計においては従来の線形空気力 モデルによる解析を主体とし，十分な余裕をもって対処す ることとした

アロー翼形態に対するフラッタ模型の風洞試験は文献 4) 10) などに見られるが, 文献 8) では本実験機と同様のクラ ンクトアロー翼を扱って打り，エンジンナセルの有無や翼 面上に設けられたフィン, スパンの短縮等のフラッタ速度 に対する影響が調べられている。このうち遷音速デイップ に打ける最大のフラッタ速度低下量はエンジンナセルつき の場合に見られ，Mach 0.75 前後の傾向から直線的に外挿 した值に対して Mach $0.98 て ゙ ~ 20 \% の$ 低下であった.

これらの結果より，線形解析值から遷音速デイップにお いて $20 \%$ のフラッタ速度低下があることを想定し，この場 合に执いても運用範囲から $20 \%$ のラッタ速度マージンが 確保できるよう，すなわち線形解析によるフラッ夕速度が 設計最大速度に対して $50 \%$ の余裕を有することを設計条件 とした。また，この際実験機主翼構造がアルミ中実構造を 含むことなどから, 構造減衰 $g$ が小さい可能性を考慮し, $g=0.01$ を仮定することとした

基本設計時には主翼，エルロン，ロケットフィンに関する モードのフラッタが眯念されたが，これらについては各フ ラッタモードに対する模型をそれぞれ製作し，風洞試験を 行うことによって設計の妥当性を確認することとした，本 稿では主翼モードに対する風洞試験結果について記述する。 


\section{3. 風洞試験模型}

3.1 相似則 主翼フラッタモードに対する風洞試験は全 機模型により行い，実験機単体形状のほか，打上げ時のロ ケットブースターの影響を調べるため, ロケットブースター をつけた打上げ形態についても試験を行った(第 1,2 図). 模型製作における実験機との相似パラメータを第 1 表に示 す. 全機模型の設計マッハ数は遷音速の影響が生じると考 えられる 0.90 とし, 模型のスケールは風洞のブロッケージ 比の制約を満足するため 0.20 とした。また打上げ時に実験 機が Mach 0.90 に到達する高度 $h=1,829 \mathrm{~m}(6,000 \mathrm{ft})$ での空気密度，および打上げ時速度が遷音速風洞における 風洞総圧 $P_{0}=80 \mathrm{kPa}$ における気流条件と対応するよう 相似則を設定した。

風洞試験で実機のフラッタ特性を確認する際, 相似則上 対応する気流条件が風洞通風領域で実現できる必要がある.

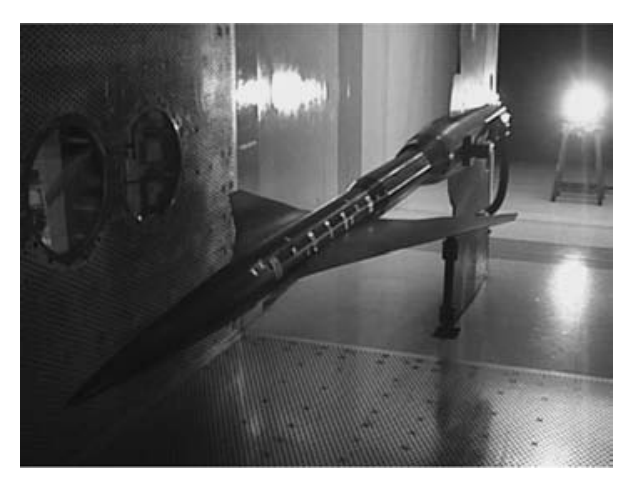

第 1 図 全機単体形態模型

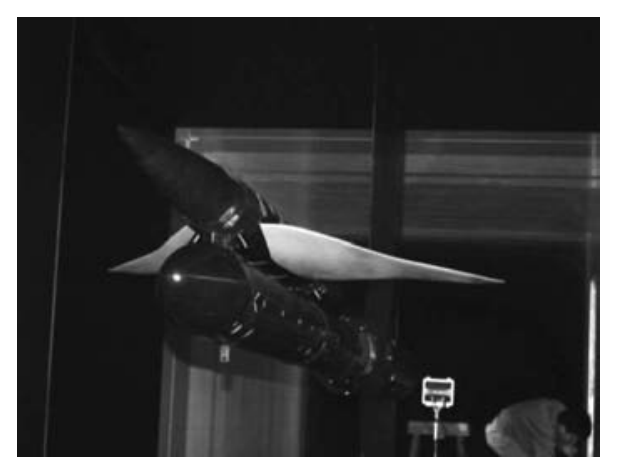

第 2 図 全機打上げ形態模型

\begin{tabular}{|c|c|c|c|c|c|}
\hline & 実験機 & 模型 & & & 無次元 \\
\hline Mach & 0.9 & 0.9 & & & 振動数 \\
\hline$V_{\mathrm{TAS}}[\mathrm{m} / \mathrm{s}]$ & 299.9 & 284.1 & & & （設計点） \\
\hline$\rho\left[\mathrm{kg} / \mathrm{m}^{3}\right]$ & 1.023 & 0.664 & ノミナル & 210 & 018 \\
\hline$h[\mathrm{~m}]$ & 1,829 & & 剛性翼 & 21.0 & 0.18 \\
\hline$P_{0}[\mathrm{kPa}]$ & & 80 & 高剛性翼 & 24.8 & 0.21 \\
\hline scale & 1.00 & 0.200 & 実験機 & 11.7 & 0.47 \\
\hline 速度比 & 1.00 & 0.947 & & & \\
\hline 密度比 & 1.00 & 0.649 & & & \\
\hline 振動数比 & 1.00 & 4.74 & & & \\
\hline 質量比 & 1.00 & 0.0052 & & & \\
\hline
\end{tabular}

しかし実験機に対して上記の相似則で模型を製作した場合, フラッ夕速度は遷音速風洞の通風域内よりも高くなること から, 剛性を相似則より低下させ, 無次元振動数を相似則 に対して 0.38 倍してフラッタが発生するよう設定した（第 2 表). また重量比についても, 模型は相似則よりやや重く, 相似則からの逸脱を許容した，実機の開発において，フラッ 夕が発生しないことを風洞試験で確認しさえすれば良い場 合（クリア試験と呼ぶ）は, フラッタが発生しないことを確 認すべき点が風洞で実現できればよいが, 本試験研究では, 遷音速フラッタ特性そのものを捉えてフラッタ特性を把握 し非線形解析コードの検証データとすることを優先した.

3.2 模型形状および構造単体および打上げ形態の全 機模型形状を第 3 図, 第 4 図に示す。全機模型において, 主翼は弾性モードを模擬し，芯金にAl7075を用いた桁リ ブ構造となっており, ウレタンフォームにより翼型を整形 した．胴体およびロケットブースターについては空力干渉 のみを考慮するため極力剛とすることとし，前胴および後 胴は樹脂, その他は SS400を用いた。 またロケットブース ターと実験機の結合も剛とした。主翼については，平面形 の他，翼型およびワープ形状を実験機に対して模擬してい るが，胴体は実験機で採用しているエリアルールを適用し た胴体ではなく, 中胴部の径は一定である。本模型では弾

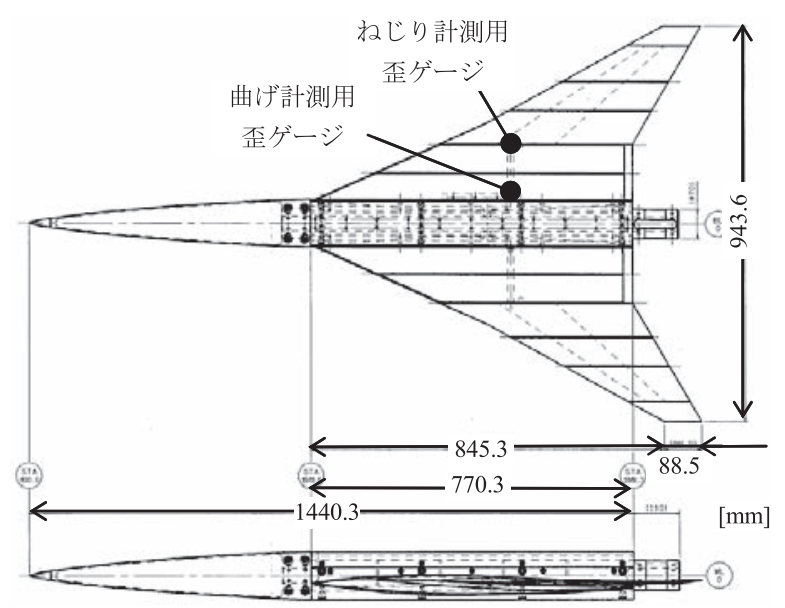

第 3 図 単体形態模型外形図

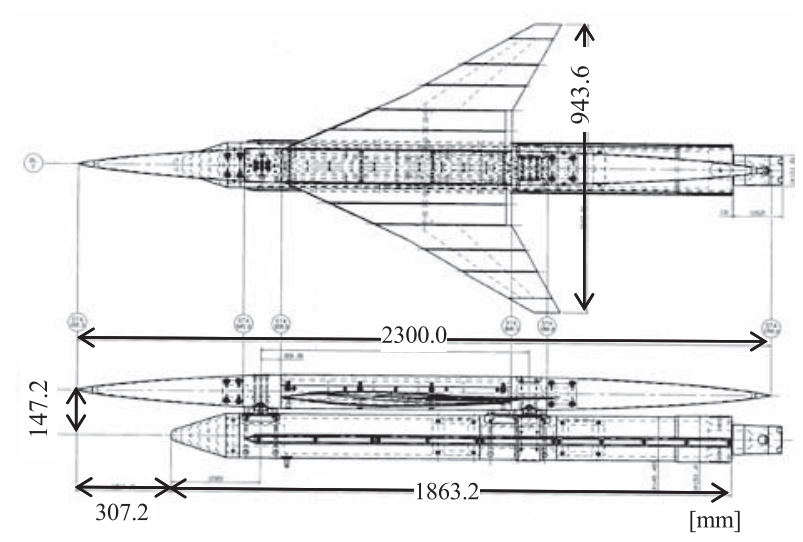

第 4 図 打上げ形態模型外形図 

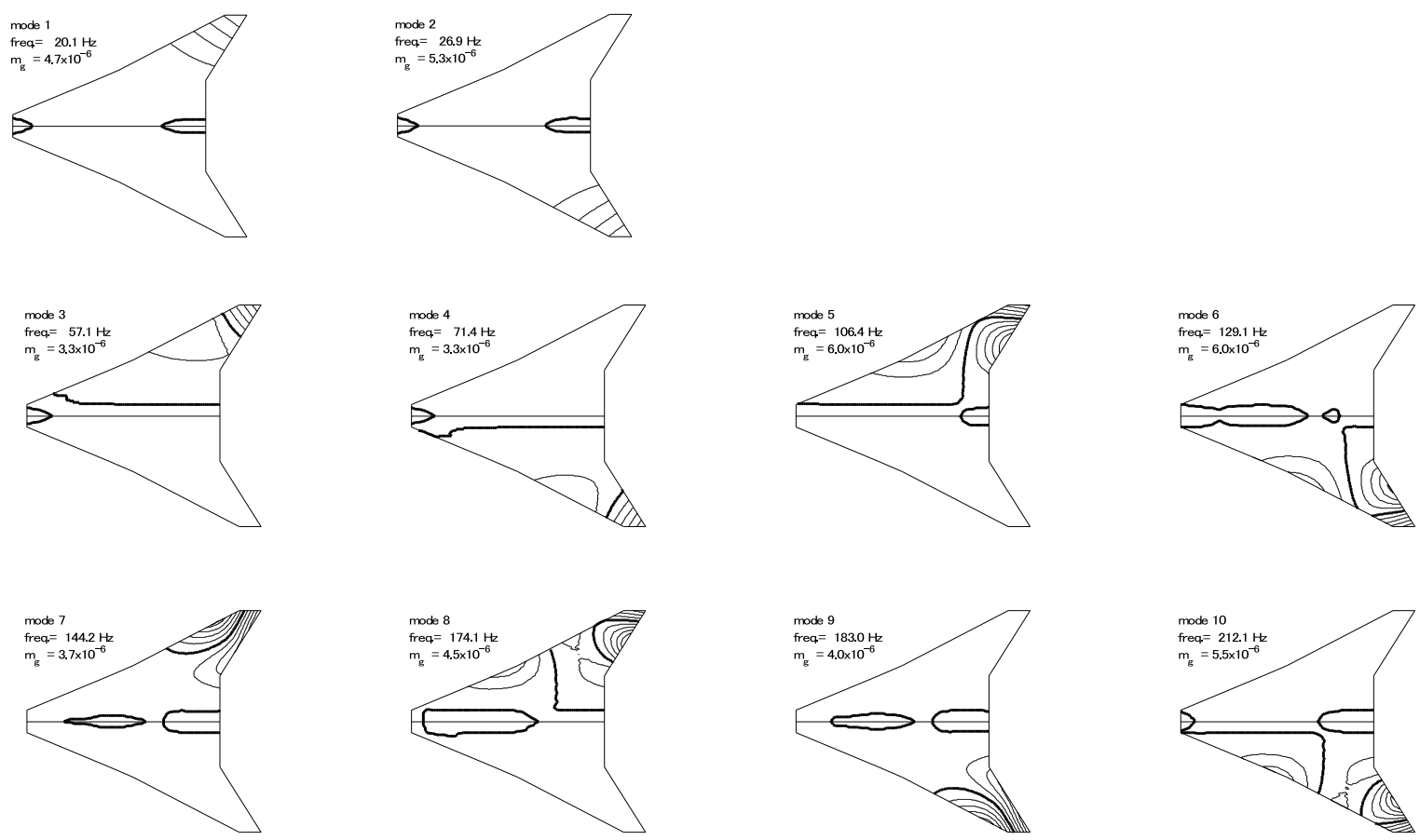

第 5 図＼cjkstart固有振動モード（全機単体形態模型解析値） $m_{\mathrm{g}}$ は一般化質量を表す。

第 3 表 全機模型固有振動数

\begin{tabular}{|c|c|c|c|c|c|c|}
\hline & & & \multicolumn{3}{|c|}{ 振動試験 } & \multirow{3}{*}{$\begin{array}{c}\text { 解析 } \\
\text { 振動数 } \\
{[\mathrm{Hz}]}\end{array}$} \\
\hline \multicolumn{3}{|c|}{ モード } & 洞内 & \multicolumn{2}{|c|}{ 洞外 } & \\
\hline$\#$ & $\begin{array}{l}\text { 左翼 } \\
\end{array}$ & $\begin{array}{l}\text { 右翼 } \\
\end{array}$ & $\begin{array}{c}\text { 振動数 } \\
{[\mathrm{Hz}]}\end{array}$ & $\begin{array}{c}\text { 振動数 } \\
{[\mathrm{Hz}]}\end{array}$ & $\begin{array}{l}\text { 構造 } \\
\text { 減衰 }\end{array}$ & \\
\hline 1 & & O & 19.6 & 21.0 & 0.012 & 20.1 \\
\hline 2 & 0 & & 25.1 & 26.5 & & 26.9 \\
\hline 3 & & 0 & 60.6 & 58.6 & 0.013 & 57.1 \\
\hline 4 & ○ & & 70.2 & 66.4 & & 71.4 \\
\hline 5 & & 0 & 114.1 & 107.8 & 0.018 & 106.4 \\
\hline 6 & $\bigcirc$ & & 132.9 & & & 129.1 \\
\hline 7 & & ○ & 144.7 & & & 144.2 \\
\hline 9 & 0 & & 183.4 & & & 183.0 \\
\hline
\end{tabular}

性主翼のモードのみ考慮することとしたため, 主翼に舵面 は装備していない。また尾翼およびロケットフィンについ ても省略した，芯金には歪ゲージを貼り付け，これにより 翼の振動状況等をモニタした，歪ゲージ配線は胴体，スティ ング内を通し，ストラット部はゴムホースを取り付けその 内部を通している。

3.3 固有振動モード NASTRAN による全機模型振動 モードの解析結果を第 5 図に示す。同図においてモード形 状は最大変位を 1 として正規化しており, 太線は節線を, 実 線は変位 0.2 ごとの等高線を表している，1４ 次モードは 右, 左翼の曲げ 1,2 次モード, $5,6,7,9$ 次モードは右, 左翼のねじり $1 ， 2$ 次モードとなっている。解析および振 動試験による振動数を第 3 表に示す。洞内振動試験は風洞 試験時と同様に右翼に低剛性翼（ノミナル剛性翼と呼ぶ）, 左翼に高剛性翼を用い後述のロール機構は固定した状態で 行った。洞外振動試験では左右とも同じ剛性の翼を取り付
けて行った試験をもとに対応するモードについて記載した. 振動試験においては, 左右の各翼において低次の 2 モード が曲げ，その次の 2 モードがねじりとなっており解析と対 応している. 振動数に若干の差が見られるが, フラッ夕解 析では解析值による振動数を用いた。

\section{4. フラッタ 解 析}

4.1 線形解析 ダブレットポイント法（DPM）を用い て線形フラッ夕解析を行った。空力パネルは片翼について 胴体, 内翼, 中間部, 外翼をスパン方向各 $1,4,2,10$ 要 素に分け，コード方向に 10 等分した. 非対称モードを考慮 するため両翼の解析を行った．空力パネルを第 6 図に示す. 非定常空気力は無次元振動数 0.001 から 5.00 まで 18 点解 析し, 固有值解析時にはその間を線形補間して使用した。

固有值解析には $p-k$ 法を用いたが，遷音速領域において は質量比 $\mu=m / \pi \rho_{\infty} b^{2} l$ の扱いに注意を要する。フラッ 夕発生条件を示す有次元諸量としては一般に動圧あるいは 等価対気速度が用いられる。したがってたとえば動圧

$$
\begin{aligned}
q_{\mathrm{d}} & =\frac{1}{2} \rho_{\infty} U_{\infty}^{2}=\frac{1}{2} \gamma R \rho_{\infty} T_{\infty} M_{\infty}^{2} \\
& =\frac{1}{2} \gamma R \frac{m}{\pi \mu b^{2} l} T_{\infty} M_{\infty}^{2}
\end{aligned}
$$

を考えると, 質量比とマッハ数を固定すれば温度のみが変 動量となる．FAA の規定では，フラッ夕速度余裕は高度一 定とした場合と, マッハ数一定とした場合の双方について, 等価対気速度で $15 \%$ の余裕を有することとされている。す なわち $\mu, T_{\infty}$ を一定として $M_{\infty}$ を変化させた場合と $M_{\infty}$ を一定として動圧を変化させた場合の双方を評価すること とされている。本試験を行った遷音速風洞は回流式風洞で 


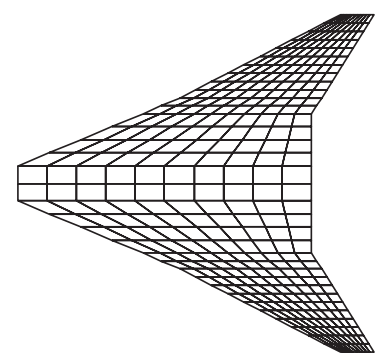

第6図 DPM 空力パネル

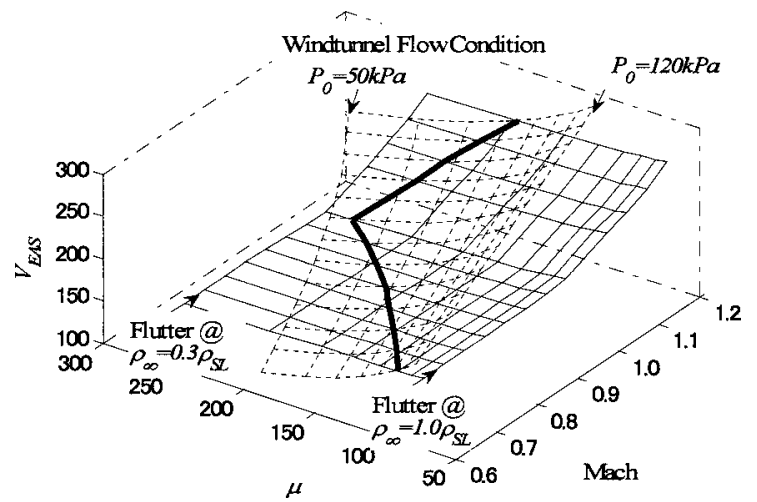

第 7 図 風洞通風領域 (点線), 各 $\mu$ に扔けるフラッタ速度 DPM 解 析值（実線）および風洞気流条件下のフラッタ速度 DPM 解 析值 (太線)

あり，風洞運用時はマッハ数および風洞総圧を設定值に制 御するとともに，冷却器により動翼によって加えられたエ ネルギーを除去し，一定時間経過後は気流温度をほぼ一定 としている。ここで, $x$ 軸にマッハ数, $y$ 軸に質量比, $z$ 軸に等価対気速度をとり，風洞試験時の総温 $T_{0}$ であった 約 $310 \mathrm{~K}$ の状態における, 風洞内で実現し得る気流状態を 示すと第 7 図の点線の曲面となる。一方，質量比すなわち 空気密度 $\rho_{\infty}$ を一定として DPM および $p-k$ 法により求 めたフラッ夕速度は同図の実線の曲面となる。 DPM 解析 值は Mach 0.60 から 1.20 において 0.05 刻みで求めた。 た だし Mach 1.00 については計算しておらず, 図では Mach 0.95 と 1.05 の解析值を結んでいる。 これと風洞気流曲面 との交線が線形解析による風洞で発生し得るフラッ夕速度 となる．質量比 $\mu$ を変化させて $p-k$ 法により求めたフラッ 夕速度は第 7 図の太線となり, これは各 $\mu$ に対して求めた フラッタ曲面と風洞気流状態を表す曲面の交線に位置して いる。これを $x-z$ 平面に投影すると第 8 図となる。この 交線は $\mu=241.7$ および $\mu=72.6 （ \rho_{\infty}=0.3 \rho_{\mathrm{SL}}$ および $\left.1.0 \rho_{\mathrm{SL}}\right)$ の間にあるが, フラッ夕速度が低いとき質量比は 大きくなるから，この模型では $\mu$ 一定としたフラッ夕境界 線より風洞試験において実現し得るフラッタ速度は, 遷音 速領域での低下量がやや大きくなる.

真対気速度一定の下で質量比 $\mu$ を変化させ $p-k$ 法で解 く際， $p$ の初期值については以下のように与えた。

1: $p_{1,1}^{l}=(-0.01+i) \omega_{l} b / U_{\infty}, \quad p_{1,2}^{l}=i \omega_{l} b / U_{\infty}$

2: $p_{2,1}^{l}=i \omega_{l} b / U_{\infty}, \quad p_{2,2}^{l}=p_{1, c}^{l}$

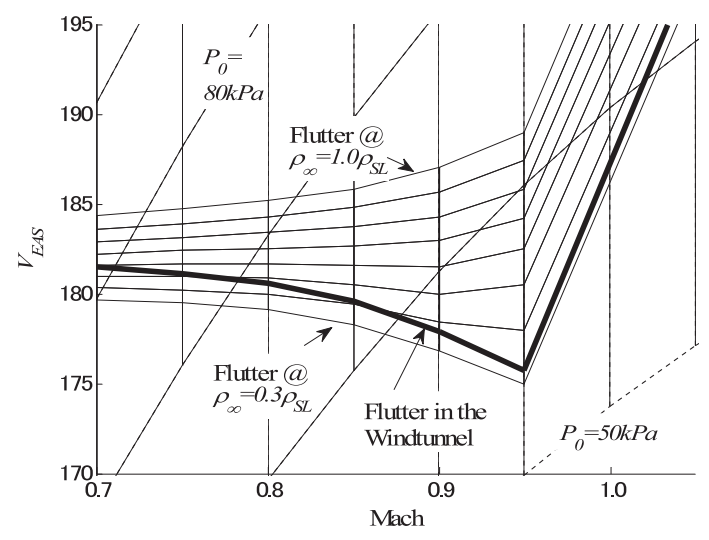

第 8 図 第 7 図を Mach- $V_{\mathrm{EAS}}$ 平面に投影した図

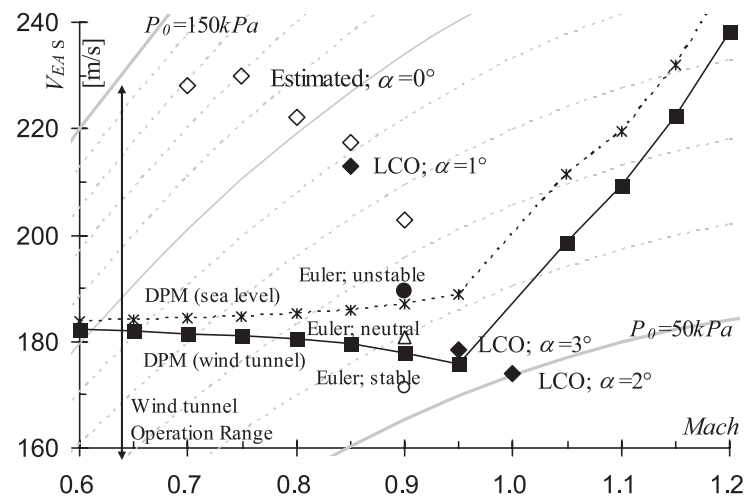

第 9 図 フラッタ境界

3: $p_{3,1}^{l}=p_{2, c}^{l}, \quad p_{3,2}^{l}=2 p_{2, c}^{l}-p_{1, c}^{l}$

$m: p_{m, 1}^{l}=p_{m-1, c}^{l}, \quad p_{m, 2}^{l}=2 p_{m-1, c}^{l}-p_{m-2, c}^{l}$

ここで $p_{a, b}^{l}$ の添字 $l$ はモード番号を, $a$ は異なる $\mu$ の番号 を， $b$ は反復番号を表し， $c$ は反復計算の収束番号を示す.

マッハ数および質量比を固定して動圧を変化させること は，便宜的には $T_{\infty}$ を変化させると解釈することができる が, この場合フラッタ解析上重要な相似パラメータである 無次元振動数 $k=\omega b / U_{\infty}$ が変わってしまうことを意味す る、第 9 図に $\rho=\rho_{\mathrm{SL}}$ とした場合，および風洞気流状態に おける DPM 解析によるフラッ夕発生速度を他の試験, 解 析結果とともに示す.

4.2 オイラー解析 本模型に対し, さらにオイラー解 析コードを用いてフラッタシミュレーションを行った。気 流条件は Mach 0.90, 等価対気速度 $V_{\mathrm{EAS}}=171,181$, $190 \mathrm{~m} / \mathrm{s}$ とし, 構造減衰は模型製作時に行った振動試験の 值 $g=0.022$ を用いた。 $V_{\mathrm{EAS}}=171 \mathrm{~m} / \mathrm{s}$ ではすべての モードが収束し, $190 \mathrm{~m} / \mathrm{s}$ では発散傾向のあるモードが見 られた。 $181 \mathrm{~m} / \mathrm{s}$ では振幅が調和振動であったため,この 点をオイラー解析によるフラッ夕発生速度とみなした。こ れは $g=0.01$ とした線形解析結果 $V_{\mathrm{EAS}}=178 \mathrm{~m} / \mathrm{s}$ とほ ぼ同じであった。 


\section{5. 風 洞 試 験}

5.1 風洞試験方法 宇宙航空研究開発機構航空宇宙技 術研究センター $2 \mathrm{~m} \times 2 \mathrm{~m}$ 遷音速風洞において単体形態は 第 1 カート, 打上げ形態は第 3 カートを用いて試験を行っ た。第 1 カートは上下左右壁面が開口比 $20 \%$ の多孔壁で, 第 3 カートは上下壁面が開口比 $6 \%$ のスリット構造をもっ ている11)。単体, 打上げ形態とも, スティングを支持装置 として使用した。

風洞試験においては, マッハ数, 風洞総圧およびスティ ングに支持された模型の迎角を変更し，各条件における模 型の振動状態を歪ゲージにより取得し, 後述のフラッタ推 定用データとした。模型は加振機構を備えておらず, 振動 は風洞の気流擾乱を加振源とした。試験の際，万一フラッ 夕が発生した場合の対策として単体形態ではフラッタを停 止させる装置を装備した。実験機および本模型とも, 線形 解析では対称モードフラッタのほうが逆対称モードよりフ ラッタ速度が低いため, ロールフリー状態からロール自由 度を拘束しフラッタを停止させる方法は使えない。このた め右翼にノミナル剛性翼, 左翼に高剛性翼と左右剛性の違 う翼を用いた。ロールを固定して左右の翼がそれぞれ独立 した振動モードを有する状態で試験を行い, フラッタ発生 時にはロールフリーとすることにより，1 次モードが低剛性 翼固定時の振動数より上昇するとともに, フラッ夕速度が 上昇することを利用した，左右非対称な翼による本フラッ 夕試験は, 左右対称翼を有する通常航空機のフラッタ特性 と等価であるとは厳密にはいえない.しかしながら，ロー ルを固定した状態では構造的に左右は独立しており, 左右 の剛性差がさほど大きくないことで静的たわみによる空気 力は左右ほぼ対称とみなすことができる。また, フラッ夕に 強く関与する動的空気力についても主に変形の大きい外翼 部で発生するため, 胴体を挟んだ左右翼間の動的変形にお ける干渉効果は無視できると考えられる。これらのことか ら, 通常のフラッ夕模型とはやや異なる形態となってはい るが, 胴体取付位置で固定する半裁模型試験と同程度にフ ラッタ試験として有効であると考えられる. フラッタ停止に はこの機構のほか, 迎角変更によりフラッタが発生した場 合, 迎角を变更前の状態に戻すことが有効な場合があった。 これと風洞の緊急停止機構を併用し, 模型を飛散させるこ となく試験を行うよう配慮した. 風洞第一コーナーベーン 前には防御網を全面に張り, 万が一飛散した場合大きな破 片が風洞の回転ブレードに達することのないよう対処した.

5.2 風洞試験結果 風洞試験はマッハ数 0.70 から 1.05 まで 0.05 刻みで行い, 風洞総圧は $50 \mathrm{kPa}$ から $109 \mathrm{kPa}$ の 範囲で行った。迎角は $0^{\circ}, 1^{\circ}, 2^{\circ}, 3^{\circ}$ について行った。 た だしすべての気流条件を網羅はしていない.これらの条件 下で主にフラッ夕推定用データ取得のため, 模型に取り付 けられた歪ゲージにより振動データを取得した。

フラッタ推定の方法として Zimmerman ら ${ }^{12)}$ の方法, Matsuzaki ら 13) の方法, 鳥居ら ${ }^{14)}$ の方法を用いた．Zimmerman らの方法では振動応答データからフラッタを引き
起こす 2 つのモードに関する振動数および減衰比 $\zeta$ を求 める必要がある。これらは取得した歪データからランダム デック法15)により求めた。 データはノミナル翼の曲げ歪を 用い, デジタル化した後, 対象とするモードの振動数付近 に帯域をもつバンドパスフィルタを適用した。閾值を標準 偏差の 2 倍としてデータを足し合わせ， 2 ないし 3 周期の 波形から振動数および減衰比 $\zeta$ を求めた。単体形態につい て, これらにより求めた振動数および損失係数 $\eta=2 \zeta$ の各 マッハ数における等価対気速度に伴う推移を第 10～12 図 (a)，(b)に示す．また，それらに対応するDPMによる解 析值を実線および点線で示す．各図 (b) の損失係数にプロッ トされた DPM の解析值は約 $180 \mathrm{~m} / \mathrm{s}$ がフラッ夕速度であ ることを示している。いずれの実験結果もこれよりフラッ 夕速度が高い. Mach 0.80 (第 11 図) においては損失係数 の実験值が $210 \mathrm{~m} / \mathrm{s}$ 付近で急激に低下しており，180 m/s 付近の DPM 解析結果と同様の傾向を示している. このた めMach 0.80 では, 解析值を参考に損失係数実験值からフ ラッ夕速度を推定することが可能である一方, 他のマッハ 数においては損失係数が 0 に近づく傾向を示す速度に達し ておらず，これからフラッ夕速度を推定することは困難で ある. 振動数については, 3 次モード実験值が低下傾向を見 せているが, 1 次モードについては線形解析值のような振 動数の上昇が見られない. 衝撃波の発生等, 遷音速領域に おける空気力の非線形性による影響は一般にフラッ夕速度 の低下をもたらす。ここでは線形解析值より実験值フラッ 夕速度が増加しており, 異なる要因が考えられる。

第 10〜12 図 (c) の $\boldsymbol{\Delta}$ 印は Zimmerman らのフラッタ余 裕係数 $F$ を示す.フラッ夕速度を推定するにはこれを外挿 し, 值が 0 となる速度を求める. F は 2 次元空力弾性モデ ルを基に求められた係数で $C_{l_{\alpha}} q_{\mathrm{d}}$ の 2 次関数で表される. $C_{l_{\alpha}}$ を一定と仮定すれば動圧 $q_{\mathrm{d}}$ の 2 次関数として 2 次回帰 曲線を求め外抻し求めることができる。.また理論的には振 動試験デー夕を用いて $V_{\mathrm{EAS}}=0 \mathrm{~m} / \mathrm{s}$ のときの值も求める ことができるが, 大域的に 2 次関数としてフラッ夕速度を 推定するのは困難であった。 また同様に各図に Matsuzaki らの方法による安定係数 $F_{(3)}^{-}$を $\square$ 印, 鳥居らの方法によ る離散フラッ夕余裕 $F_{z}$ を $\bigcirc$ 印で示す。これらの係数はい ずれも得られた離散デー夕から直接求められるが, フラッ 夕に関連する 2 モードの帯域データを取り出す必要がある. また，バンドパスフィルタを適用した場合にフィルタ自身 を同定してしまう場合もあり，ここでは $150 \mathrm{~Hz}$ 付近でダウ ンサンプリングすることにより高周波側のデータを削除し, ハイパスフィルタを用いてデータの帯域を限定した。フラッ 夕推定は図示したものの他 Mach $0.75,0.85$ の迎角 $0^{\circ} に$ ついても行った. $F_{(3)}^{-}$は Mach 0.70 等, 上に凸となる傾 向が見られる。 $F_{z}$ はZ Zimmerman らの方法同様 $C_{l_{\alpha}} q_{\mathrm{d}}$ の 2 次関数となることから, これらの推定パラメータに動圧 $q_{\mathrm{d}}$ に関する 2 次回帰曲線を適用し, 3 つのパラメータから 推定されるフラッタ速度の平均值を本試験のフラッタ速度 推定值とした。これらの值を第 9 図に〉印で示す。ただし Mach 0.90 については取得したデータの速度範囲が狭いた 


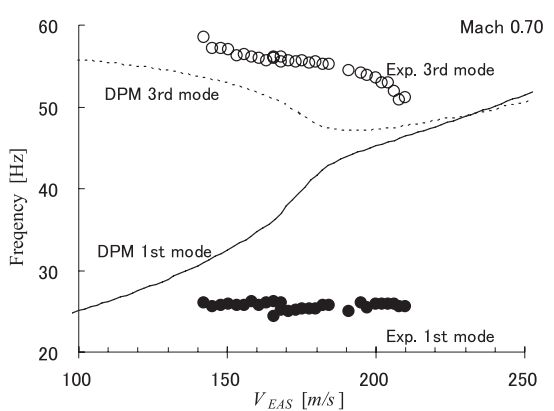

(a) 振動数

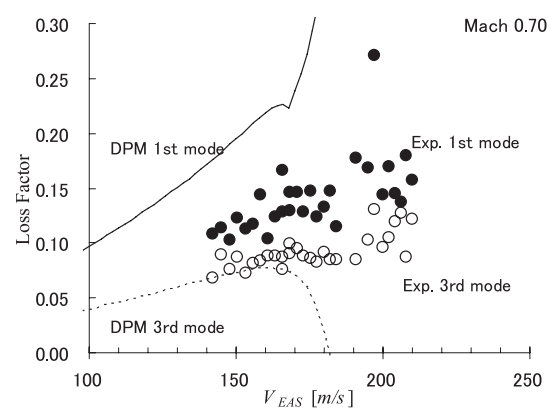

(b) 隇衰

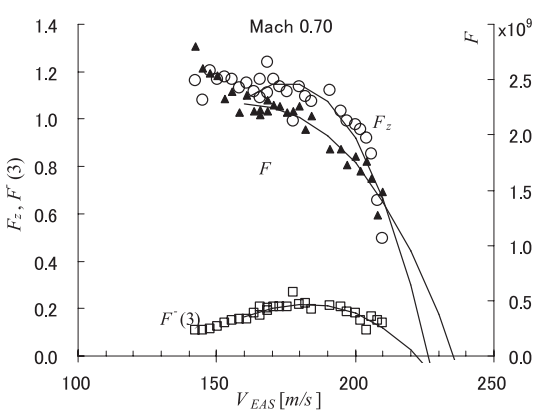

(c) 推定パラメータ

第 10 図 Mach 0.70, 迎角 $0^{\circ}$ における等価対気速度に伴う各状態量の推移

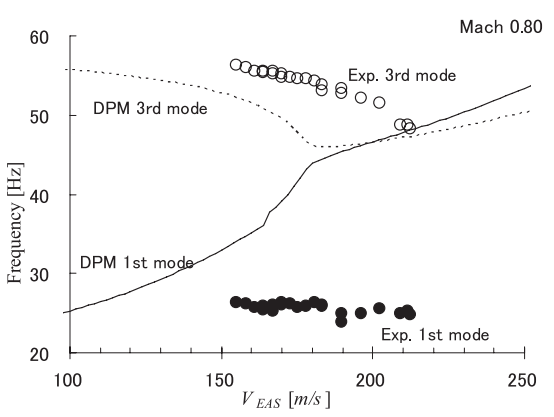

(a) 振動数

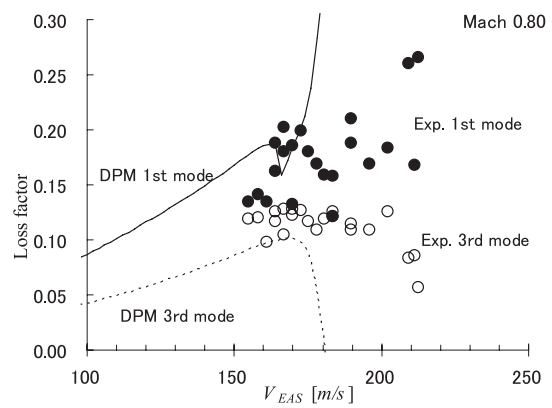

(b) 減衰

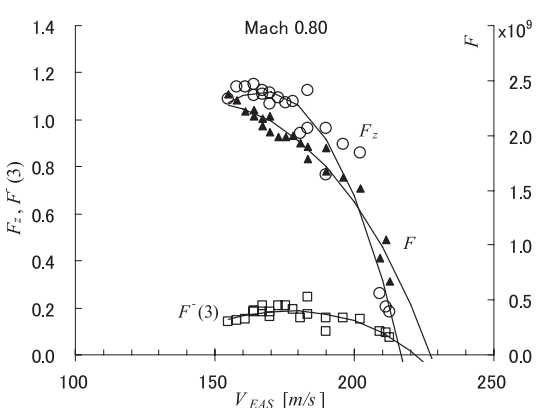

(c) 推定パラメータ

第 11 図 Mach 0.80 , 迎角 $0^{\circ}$ における等価対気速度に伴う各状態量の推移

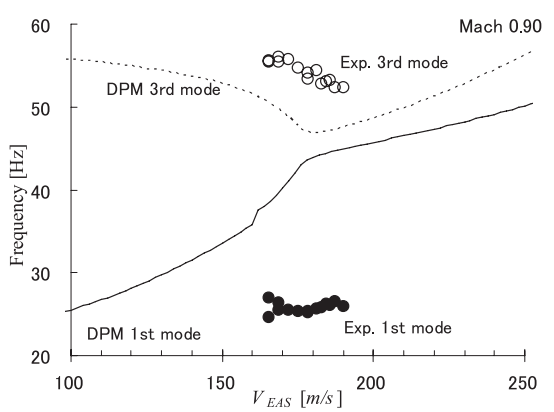

(a) 振動数

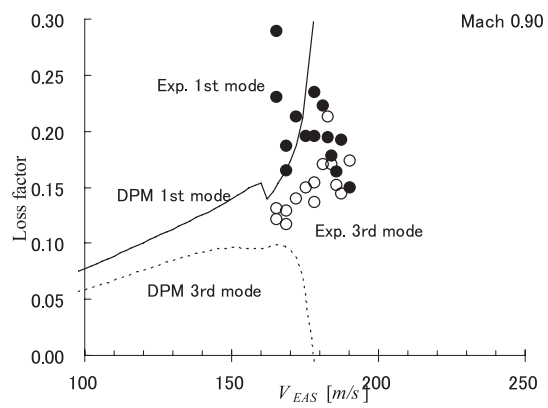

(b) 減衰

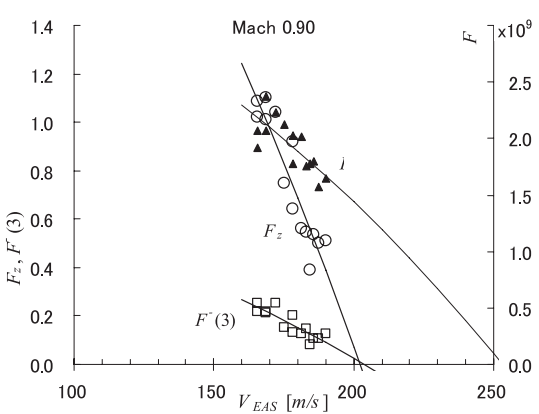

(c) 推定パラメータ

第 12 図 Mach 0.90 , 迎角 $0^{\circ}$ における等価対気速度に伴う各状態量の推移

め線形近似式を適用し, Zimmerman らの方法は推定速度 が大きく離れていることから除外し， $F_{(3)}^{-}$および $F_{z}$ の 2 つの推定值の平均を採用した. なお，第 10〜12 図 (c) に実 線で各パラメータの近似線を示すが, 横軸は動圧ではなく 等価対気速度のため近似曲線は 4 次曲線, Mach 0.90 につ いては 2 次曲線となっている.

風洞試験の際, 単体形態では 3 点のフラッタ発生を観測し た.フラッタが発生した Mach 0.95, 迎角 $3^{\circ}$ および Mach 1.00 , 迎角 $2^{\circ}$ についてはフラッ夕発生が風洞通風範囲の動 圧下限付近だったため推定に必要なデー夕は得られなかっ

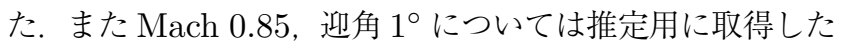
データが $V_{\mathrm{EAS}}=194 \mathrm{~m} / \mathrm{s}$ 以上のみのため, 推定を行うに は不十分だった。これらのフラッ夕発生条件および振動数 を第 4 表に示す。またこれらの点を第 9 図に・印で示す. これらはいずれもリミットサイクル振動（LCO）であった.
第 4 表 フラッタ発生条件（単体形態）

\begin{tabular}{cccc}
\hline Mach & $V_{\text {EAS }}[\mathrm{m} / \mathrm{s}]$ & $\alpha[\mathrm{deg}]$ & $f[\mathrm{~Hz}]$ \\
\hline 0.85 & 213 & 1.0 & 45.2 \\
0.95 & 178 & 3.0 & 39.8 \\
1.00 & 174 & 2.0 & 36.9 \\
\hline
\end{tabular}

各ケースとも同じマッハ数および等価対気速度においてそれ ぞれ $1^{\circ}$ 小さい迎角ではフラッタが発生しておらず, フラッ 夕の迎角依存性が認められた。フラッタ速度の推定值なら びに実際に発生したフラッタの状況から, フラッタ速度は Mach 0.85 程度から低下していると見られる。試験時の目

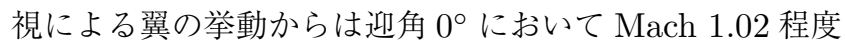
で遷音速ディップの底となっていると思われる. Mach 0.80 におけるフラッ夕速度推定 $222 \mathrm{~m} / \mathrm{s}$ に対して Mach 1.00, 迎角 $2.0^{\circ}$ でのフラッタ速度 $174 \mathrm{~m} / \mathrm{s}$ は $21 \%$ のフラッタ速 
度低下であり，設計時に設定した $20 \%$ に対してほぼ同等の 低下量になっている。

一方打上げ形態では Mach $0.95, \alpha=2.0^{\circ}$ に扔いて $V_{\mathrm{EAS}}=182 \mathrm{~m} / \mathrm{s}$ でフラッタが発生した。これは線形解 析值に対して $27 \%$ のフラッタ速度低下で, 設計条件を満た さない結果となった．打上げ形態についてはデータ点数が 不十分なため精度良いフラッ夕速度推定はできなかった。

\section{6. 実験結果に対する考察}

6.1 構造的要因 線形フラッタ解析に対して遷音速領 域ではフラッ夕速度の低下が予測された。 フラッタ速度の 推定值等実験結果のみを見れば，遷音速領域でのフラッタ 速度の低下が見られるが, 線形解析結果に対しては逆にフ ラッタ速度が高かった．これについてまず構造的要因から 考察する。

6.1.1 固有振動数変化の影響 本風試模型の構造はアル ミの芯金にウレタン発泡剂を貼り付けて翼型を整形してい る, 通風による荷重や, フラッ夕発生による振動により, ウ レタンの接着剝離や塑性変形等が模型の剛性に変化を及ぼ し, 振動数や構造減衰が変化する可能性がある. 模型の健全 性をモニタするため風洞休止の際には振動数を計測して変 化の有無を確認した。本風試ではフラッ夕発生等により模 型の固有振動数が大きく変化することはなかったが, モー ドによってはパワースペクトルのピークが不明瞭なことも あり，若干のばらつきが見られた。これらの平均值拉よび 標準偏差 $\sigma$ を第 5 表に示す.

振動モードのモデル誤差がフラッタ速度に及ぼす影響を 調べるため，まず全機モードに対する高次項の影響を調べ た (第 13 図).フラッタ解析で使用するモード数を 10 モー ドから 7 モードまで減らしてもフラッ夕速度への影響はほ とんど見られないが，7次モードを省略するとフラッタ速 度は $7.1 \%$ 増加している。 また 10 次モードまで考慮したと きの Mach 0.80 に扔けるフラッ夕発生速度, すなわち零固 有值に対応する固有ベクトルの各モードに対応する成分の 大きさを 1 次モードの要素の大きさで基準化したものを第 6 表に示す. 7 次モードの影響が比較的大きくなっており, これらのことから少なくとも 7 次モードまで考慮して解析 を行うべきと考えられる。

次に線形フラッ夕解析に扔ける各固有振動数の影響を調 べた．前述の検討から影響が大きいと考えられる $1,3,7$ 次モードの振動数を $\pm 2, \pm 5 \%$ 変化させフラッタ速度への 影響を検討した，結果を第 14 図に示す.1 次モードの振動 数増加はフラッ夕速度の低下を, 3,7 次モードの振動数の 増加はフラッタ速度の低下をもたらす．3 次モードの振動 数の変化の影響が最も大きいが $5 \%$ 増加したときにフラッ 夕速度の低下は $5.3 \%$ となっている。

また第 10〜12 図の減衰の変化を見ると, フラッタ発生 点付近では損失係数の勾配が大きく, 構造減衰の違いがフ ラッタ速度に及ぼす影響は小さいと考えられる。

6.1 .2 スティング剛性の影響 模型支持装置にはスティ ングを使用しており, 単体形態では胴体後部にロール固定

\begin{tabular}{|c|c|c|c|c|c|c|}
\hline 第 5 表 & $\begin{array}{l}\text { 風洞試! } \\
\text { 有振動 }\end{array}$ & $\begin{array}{l}\text { 㑒期間 } \\
\text { 如の変 }\end{array}$ & の固 & 第 6 表 & $\begin{array}{l}\text { フラッタ速度に } \\
\text { 固有ベクトル }\end{array}$ & $\begin{array}{l}\text { おける } \\
\text { 大きさ }\end{array}$ \\
\hline & Freq. & $\sigma$ & $\bar{\sigma}$ & & (Mach 0.80) & \\
\hline Mode & {$[\mathrm{Hz}]$} & {$[\mathrm{Hz}]$} & [\%] & & Magnitude of & $\overline{\text { Ratio }}$ \\
\hline 1 & 19.6 & 0.15 & 0.8 & Mode & eigen vector & {$[\%]$} \\
\hline 2 & 25.1 & 0.14 & 0.6 & 1 & 1.0000 & $\begin{array}{l}55.3 \\
\end{array}$ \\
\hline 3 & 60.6 & 0.99 & 1.6 & 2 & 0.1120 & 6.2 \\
\hline 4 & 70.2 & 1.28 & 1.8 & 3 & 0.5855 & 32.4 \\
\hline 5 & 114.1 & 4.91 & 4.3 & 4 & 0.0324 & 1.8 \\
\hline 6 & 132.9 & 1.29 & 1.0 & 5 & 0.0126 & 0.7 \\
\hline 7 & 144.7 & 2.61 & 1.8 & 6 & 0.0021 & 0.1 \\
\hline 8 & 183.4 & 3.22 & 1.8 & 7 & 0.0575 & 3.2 \\
\hline & & & & 8 & 0.0024 & 0.1 \\
\hline & & & & 9 & 0.0025 & 0.1 \\
\hline & & & & 10 & 0.0002 & 0.0 \\
\hline
\end{tabular}

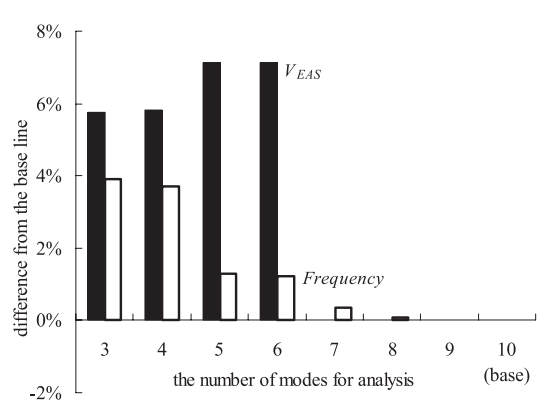

第 13 図 考慮するモード数のフラッタ速度解析值への影響（Mach $0.80)$

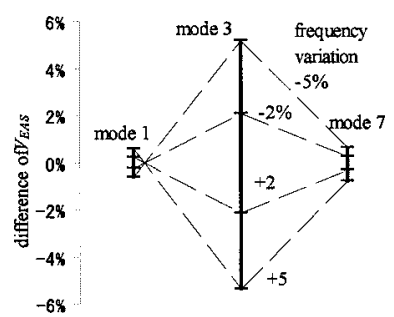

第 14 図 固有振動数のフラッタ速度解析值への影響（Mach 0.80）

装置を介してスティングに結合し, 片持ち状態となる。胴体 およびロール固定装置はスチール製で，剛体を仮定してい るが, 実際には低い振動数の固有振動モードを有すること が懸念される。このためロール固定装置-胴体部の影響につ いて解析を行った。 ロール固定装置すなわち模型胴体後端一 スティング先端間は $725 \mathrm{~mm}$ で, 外形は最大径 $\phi 140 \mathrm{~mm}$, 内部はロール固定装置等により複雑な構造となっている. た だし簡単化のため外径 $100 \mathrm{~mm}$, 内径 50〜98 $\mathrm{mm}$ のスチー ル製の胴体を仮定し FEM 解析を行った。いずれもスティ ングのヨーおよびピッチングを伴うモードが現れた。 この うち内径 $50 \mathrm{~mm}$ としたときヨー, ピッチいずれも $44.7 \mathrm{~Hz}$ とフラッタ振動数に近いモード, 内径 $98 \mathrm{~mm}$ としたとき $18.3,18.5 \mathrm{~Hz}$ と 1 次に近いモードの振動数となった。 この うち内径 $50 \mathrm{~mm}$ としたとき, Mach 0.80 におけるフラッタ 速度が支持部を考慮しないときに比べて $3.1 \%$ の増加となっ た。このように構造的要因によりフラッタ速度が解析值よ りも実際に高くなっている可能性があるが, Mach 0.80 に 
おけるフラッタ速度実験值（推定值）は解析值より $23 \%$ 高 く，その差をすべて説明できるには至らなかった。

6.2 空力的要因 ポテンシャル流れ理論に基づく理想 的な非定常空気力は, 実際よりも大きく見積もられること が知られており，実験值との差の要因の一つとして考えら れる ${ }^{16,17)}$. また線形解析值よりも風洞試験におけるフラッ 夕速度が増加する例が文献 18)に見られる. 文献 18)では $H / 2 b=2.4$ という大きな二次元翼模型を用いた際, 風洞 壁の影響により解析值よりも約 $20 \%$ 高いフラッタ速度と なっている. 本模型では翼根部で $H / 2 b=2.6$, 翼端部で $H / 2 b=23$ の三次元翼模型であり, 風洞壁形状や開孔比 にも差はあるが，この風洞壁の影響も可能性として考えら れる。

6.3 空弾設計の妥当性 本風洞試験における遷音速領域 でのフラッタ速度低下量は, 単体形態で $21 \%$, 打上げ形態 では線形解析值に対してフラッタが観測された点で $27 \%$ で あった。これは当初設計方針の $20 \%$ 低下には収まっていな い. 線形解析あるいは亜音速領域におけるフラッ夕速度に 対して遷音速領域でのフラッ夕速度低下量を 20 ～ $30 \%$ と見 積もることは, 設計初期の段階では適度であるかもしれな いが，フラッタ安全性を保証するには非線形解析あるいは 実験によりその特性を把握する必要があることはいうまで もない.

\section{7.お おりに}

本風洞試験は NEXST-1 開発の一環として行われたもの である.今後クランクトアロー形態の超音速旅客機が開発 される際には，これを基にさらに詳細なデー夕を積み上げ ることが期待される。遷音速風洞試験においては空気密度 が変化するため, 線形解析值を参考にする場合には質量比 の変化に気をつける必要がある。模型や風洞の損傷を防ぐ ためには実際にフラッタを発生させずにフラッタ速度の推 定手法を使う必要があるが, 十分な速度領域のデータを取 るとともに複数のパラメー夕を参考に推定するのが良いと いえる.

本模型の遷音速フラッタ特性として外翼主体のリミット サイクルとなること, フラッ夕速度の落ち込みが $20 \%$ ない しそれ以上であること，迎角に対する依存性があることな どが確認された。またデイップの底はMach 1.02 付近にあ り，デイップの落ち込みはMach 0.85 程度から始まり比較 的厚翼に近い Mach 数範囲の広い傾向を示した。

フラッ夕速度の実験值が線形解析より高くなることに対 していくつかの可能性を示したが，これを検証するには詳 細な振動モードの計測, 圧力分布や力計測等のデータを取 得すべきと考えられる. 圧力分布については定常圧力であっ ても参考データとして有用である.

本試験および解析により，遷音速ディップでのフラッタ 速度の低下が, 設定よりもやや大きかったことを明らかに し, 今後の空力弾性機体設計に対する知見を示すことがで
きた。ただし実験機実機においてはフラッタ余裕が十分大 きかったため設計変更等は行っていない. また第 1 回目の 飛行試験後, 更なる信頼性向上の観点からフラップに関し て改修を行ったことを付記する。

本論文執筆に当たっては名古屋大学上田哲彦教授にご助 言を頂いた。ここに感謝の意を表す.

\section{参 考 文 献}

1) McLean, F. E.: Supersonic Cruise Technology, NASA SP$472,1985$.

2) Turner, M. J. and Grande, D. L.: Study of Metallic Structural Design Concepts for an Arrow Wing Supersonic Cruise Configuration, NASA CR-2743, 1977.

3) Hitch, H. P. Y.: Concorde Dynamics - a Review, AIAA Paper 72-381, 1972.

4) Ruhlin, C. L. and Pratt-Barlow, C. R.: Transonic Flutter Study of a Wind-Tunnel Model of an Arrow-Wing Supersonic Transport, AIAA Paper 81-0654, 1981.

5) Doggett, Jr. R. V. and Ricketts, R. H.: Some Experimental and Theoretical Flutter Characteristics of an Arrow-Wing Configuration, AIAA Paper 77-422, 1977.

6) Doggett, Jr. R. V. and Ricketts, R. H.: Effects of Angle of Attack and Ventral Fin on Transonic Flutter Characteristics of an Arrow-Wing Configuration, NASA TM-81914, 1980.

7) Durham, M. H., Cole, S. R., Cazier, Jr. F. W., Keller, D. F., Parker, E. C. and Wilkie, W. K.: Experimental Transonic Flutter Characteristics of Supersonic Cruise Configurations, AIAA Paper 90-0979, 1990.

8) Keller, D. F. and Bullock, E. P.: Span Redunction Effects on Flutter Characteristics of Arrow-Wing Supersonic Transport Configurations, NASA TP-3077, 1991.

9) Schuster, D. M., Spain, C. V., Turnock, D. L., Rausch, R. D., Hamouda, M., Vogler, W. A. and Stickwell, A. E.: Development, Analysis and Testing of the High Speed Research Flexible Semispan Model, NASA CR-1999-209556, 1999.

10) Silva, W. A., Keller, D. F., Florance, J. R., Cole, S. R. and Scott, E. C.: Experimental Steady and Unsteady Aerodynamic and Flutter Results for HSCT Semispan Models, AIAA Paper 2000-1697, 2000.

11）鈴木弘一, 細江信幸, 中村正剛, 小池 陽, 飯島由美, 小国保男, 河本 嚴, 海老原正夫 : 航技研遷音速風洞の測定胴設備改修の概 要について, 航空宇宙技術研究所資料 TM-674, 1995.

12) Zimmerman, N. H. and Weissenburger, J. T.: Prediction of Flutter Onset Speed Based on Flight Testing at Subcritical Speeds, J. Aircraft, 1 (1964), pp. 190-202.

13) Matsuzaki, Y. and Ando, Y.: Estimation of Flutter Boundary from Tandom Responses Due to Turbulence at Subcritical Speeds, J. Aircraft, 18 (1981), pp. 862-868.

14）鳥居弘志, 松崎雄嗣 : ARMA モデルに基づくフラッタ推定法（第 1 報) フラッタ推定パラメータの提案, 日本航空宇宙学会論文集, 47 (1999), pp. 443-448.

15) Cole, H. A., Jr.: On-Line Failure Detection and Damping Measurement of Aerospace Structures by Random Decrement Signatures, NASA CR-2205, 1973.

16) Abel, I., Perry, B., III and Newsom, J. R.: Comparison of Analytical and Wind-Tunnel Results for Flutter and Gust Response of a Transport Wing with Active Controls, NASA TP-2010, 1982.

17） ACT 研究会：高アスペクト比翼のフラッタ制御実験（第 1 報）, 航空宇宙技術研究所報告, TR-978, 1988.

18）齊藤健一, 玉山雅人, 吉本周生: 遷音速フラッ夕発生時の非定常 空気力について, 第 48 回飛行機シンポジウム, 静岡, 2010, pp. 136-140. 